\title{
Coexistence of Legionella pneumophila Bacteria and Free-Living Amoebae in Lakes Serving as a Cooling System of a Power Plant
}

\author{
Elżbieta Żbikowska • Hanna Kletkiewicz • \\ Maciej Walczak • Aleksandra Burkowska
}

Received: 4 April 2014 / Accepted: 9 July 2014 / Published online: 29 July 2014

(C) The Author(s) 2014. This article is published with open access at Springerlink.com

\begin{abstract}
The study was aimed at determining whether potentially pathogenic free-living amoebae (FLA) and Legionella pneumophila can be found in lakes serving as a natural cooling system of a power plant. Water samples were collected from five lakes forming the cooling system of the power plants Pątnów and Konin (Poland). The numbers of investigated organisms were determined with the use of a very sensitive molecular method-fluorescence in situ hybridization (FISH). The result of the present study shows that thermally altered aquatic environments provide perfect conditions for the growth of L. pneumophila and amoebae. The bacteria were identified in the biofilm throughout the entire research period and in the subsurface water layer in July and August. Hartmanella sp. and/or Naegleria fowleri were identified in the biofilm throughout the entire research period.
\end{abstract}

E. Żbikowska $(\bowtie)$

Department of Invertebrate Zoology, Faculty of Biology and Environment Protection, Nicolaus Copernicus University, Lwowska 1, 87-100 Toruń, Poland e-mail: ezbikow@umk.pl

\section{H. Kletkiewicz}

Department of Animal Physiology, Faculty of Biology and Environment Protection, Nicolaus Copernicus University, Torun, Poland

\section{Walczak · A. Burkowska}

Department of Environmental Microbiology and

Biotechnology, Faculty of Biology and Environment

Protection, Nicolaus Copernicus University,

Toruń, Poland
Keywords FLA $\cdot$ Hartmanella sp. Naegleria fowleri . Legionella pneumophila $\cdot$ Biofilm $\cdot$ Environment and public health $\cdot$ Cooling system

\section{Introduction}

Legionella spp. are Gram-negative non-encapsulated, non-endospore-forming bacilli, ranging in size from $0.3-0.9 \mu \mathrm{m} \times 2-20 \mu \mathrm{m}$, with a single, polar flagellum. First identified in 1976, Legionella spp. (Saint and Ho 1999; Gomez-Valero et al. 2009; Huang and Hsu 2010) are one of the main groups of pathogenic bacteria transmitted via water (Fields et al. 2002). Human infection by Legionella pneumophila usually results from inhaling aerosol - droplets of water which contain bacterial cells (Pancer et al. 2008; Declerck 2010). In Europe, L. pneumophila are responsible for $95 \%$ of all reported cases of legionellosis, the remaining cases being caused by Legionella longbeachae (Whiley and Bentham 2011).

Although Legionella can multiply in temperatures ranging from 20 to $40{ }^{\circ} \mathrm{C}$ (Grabińska-Łoniewska 2010; Diederen 2008), the optimum temperature for their growth is $32-35{ }^{\circ} \mathrm{C}$. However, they can survive in an aquatic environment in temperatures ranging from 0 to $68{ }^{\circ} \mathrm{C}$ and with $\mathrm{pH}$ ranging from 5.0 to 8.5 (Diederen 2008). They need aerobic conditions, oxygen concentration being another determinant of their growth. L. pneumophila are known to thrive in biofilms which form at the solid-liquid or at liquid-air interface (floating biofilm, surface microlayer) (Flemming et al. 
2000). The natural habitat of Legionella spp. is the aquatic environment: they are found both in natural water bodies (lakes, ponds, rivers, thermal waters) and in man-made (anthropogenic) ones (swimming pools, water supply systems, cooling towers) (Huang and Hsu 2010). They have also been recovered from compost, sewage, soils (Devos et al. 2005), and saline water (Żbikowska et al. 2013; Walczak et al. 2013).

The number of these microorganisms is usually higher in man-made ecosystems providing perfect conditions for their growth (Guyard and Low 2011) than in natural ecosystems, where their number is usually low (Steinert et al. 2002). The growth and survival rate of Legionella in the environment depend mainly on their ability to develop symbiotic relationships with protists. Legionella have been identified inside several ciliates including Tetrahymena and Cyclidium species as well as inside amoeba species belonging to Acanthamoeba, Hartmanella, Valkampfia, and Naegleria genera (Lee and West 1991; Paszko-Kolva et al. 1993; States et al. 1989; Kramer and Ford 1994; Henke and Seidel 1986; Fields 1996; Vandenesch et al. 1990), referred to as freeliving amoebae (FLA), ubiquitous and opportunistic protists, which can induce human and animal diseases (Dendana et al. 2008).

One FLA species in particular, Naegleria fowleri, is identified as the causative agent of primary amoebic meningoencephalitis (PAM), an acute, rapidly fatal disease of the central nervous system that is observed in young people after exposure to contaminated water in public swimming pools or lakes (Martinez 1985). In the majority of the reported cases, the invasion occurred in freshwater bodies in swimmers or divers. The infection develops after the amoeba enters the nasal passage, then penetrates through the ethmoid bone and travels to the brain (Fiordalisi et al. 1992), after which the victim dies within several days. Although PAM is not a common disease, an increase in the number of the recorded cases has been observed since the 1990s. (De Napoli et al. 1996; Taylor et al. 1996; Marciano-Cabral et al. 2003; Gyori 2003; Okuda et al. 2004; Schuster and Visvesvara 2004; Craun et al. 2005). Moreover, accelerated multiplication of Naegleria was observed in the presence of several strains of Enterobacteriaceae (Kyle and Noblet 1985; Singh and Dutta 1984). Thermally altered environments, for example lakes altered by power plants, provide highly favorable conditions for the growth of thermophilic Naegleria and thermophilic bacteria, the latter being a vital element of amoebae diet (Tyndall et al. 1989; Sykora et al 1983). These environments (lakes) often are used by people for recreation (swimming, surfing). Both FLA and thermophilic bacteria can thrive in thermally polluted water bodies including water systems used by industries. Taking into consideration that these two groups of thermophilic organisms include potential pathogens of humans and animals, regular monitoring of thermally altered water bodies should be a crucial part of environmental diagnostics. Data on the spread of $N$. fowleri in the environment are collected mainly in the USA (Stevens et al., 1977; John and Howard 1995), Australia (Mackowiak et al. 2010), New Zealand (Brown et al. 1983), and Asia (Shin and Im 2004), where natural thermal water conditions promote the expansion of the species. In Europe, despite the alarming statistics (17 fatal cases of PAM in Ústí nad Labem in the years 1962-1965, Červa and Novák 1968), the problem of deadly amoebae in heated waters was abandoned, probably due to the inefficient diagnostic techniques.

$N$. fowleri is the only potentially pathogenic species out of nearly 30 belonging to the Naegleria genus (Martinez 1985; Visvesvara et al. 2007). Due to several morphological similarities, non-specific behavior in a culture, as well as a typical antigenic structure, $N$. fowleri is difficult to differentiate from other thermotolerant species, particularly from non-pathogenic Naegleria lovaniensis (Reveiller et al. 2002). The introduction of molecular diagnostic techniques significantly increased chances of obtaining reliable data on the spread of the pathogenic amoebae in the environment (Pélandakis and Pernin 2002; Reveiller et al. 2002; Marciano-Cabral et al. 2003).

The present paper is aimed at filling gaps in the knowledge of the distribution of thermophilic, potentially pathogenic FLA and coexisting Legionella sp. in the biofilm of thermally polluted lakes serving as a cooling system of a power plant located in central Europe (Poland). The biofilm formed on the liquid-air interface was monitored for the presence of thermophilic pathogens due to the regular presence of Gram-negative bacteria including Legionella sp. and L. pneumophila. Bacteria in this formation build a mucopolysaccharide matrix, enabling them to colonize free-living amoebae.

\section{Materials and Methods}

Water samples were collected from five lakes forming the cooling system of the power plants Konin (founded 
in 1958 and its electric power is 198 MW) and Pątnów (founded in 1967 and its electric power is $200 \mathrm{MW}$ ). The heated water from the Konin power plant is discharged to lakes Gocławskie, Pątnowskie, and Mikorzyńskie. From the Pątnów power plant, the heated water is discharged to lakes Pątnowskie, Mikorzyńskie, and Licheńskie. From Licheńskie Lake, the water flows to Ślesińskie Lake (large loop). While flowing, the water cools and is taken by the power plants. Joined with a system of canals, the lakes have a total length of $26 \mathrm{~km}$. The lake-canal system is a closed loop (in terms of the power plant operation), where the water flow is regulated by water culverts and pumping stations. Water from the lakes cools the power generation units of both power plants and returns to the lakes heated (Fig. 1).

All five lakes are used for recreation (swimming, surfing). Above lakes Mikorzyn, Ślesin, and Pątnów are mainly holiday resorts. These lakes are also centers of sailings. Lake Gocławskie is mainly used as a reservoir for surfing, and Lichen Lake is used for recreation, swimming, and fishing.

The temperature of the water discharged from the power plant is on average between 6.0 and $9.0^{\circ} \mathrm{C}$ higher than the temperature of the water collected from the lakes. This has led to the permanent increase in the water temperature, ranging between 26 and $31^{\circ} \mathrm{C}$ in summer. All the lakes have aerobic conditions in the epilimnion layer.
Water samples were collected from all five lakes in May, July, August, and October. Each sampling procedure involved collecting water from the biofilm, 11 (the surface microlayer to the maximum depth of $150 \mu \mathrm{m}$ ), using a plexiglass plate and from a depth of about $20 \mathrm{~cm}, 11$, using a sterile pipette. Samples were not collected from sediments because of anoxic conditions. Water samples were transferred to sterile glass bottles and then transported to the laboratory at $7{ }^{\circ} \mathrm{C}$.

The following physicochemical parameters of water were measured: temperature, $\mathrm{pH}$ value (with the ELMETRON $\mathrm{pH}$ meter), and oxygen saturation (with the HANNA Instruments oximeter). The numbers of bacteria belonging to Legionella sp. and L. pneumophila and the investigated eukaryotic organisms (Naegleria sp., N. fowleri, and Hartmanella sp.) were determined with the use of the molecular fluorescence in situ hybridization (FISH) method.

In the laboratory, water samples from each lake were averaged, then fixed with formamide and filtered through polycarbonate membrane filters with a $0.22-\mu \mathrm{m}$ pore size in order to capture particles bigger than $0.22 \mu \mathrm{m}$. The hybridization was performed according to Grimm et al. (2001). Bacterial cells retained on the surface of the membrane were hybridized using Legionella-specific fluorescence-labelled (with dye CY3) oligonucleotide probes LEG705 and LEGPNE1 and fluorescein-labelled eukaryote-specific probes

Fig. 1 The cooling system of the power plants Pątnów and Konin

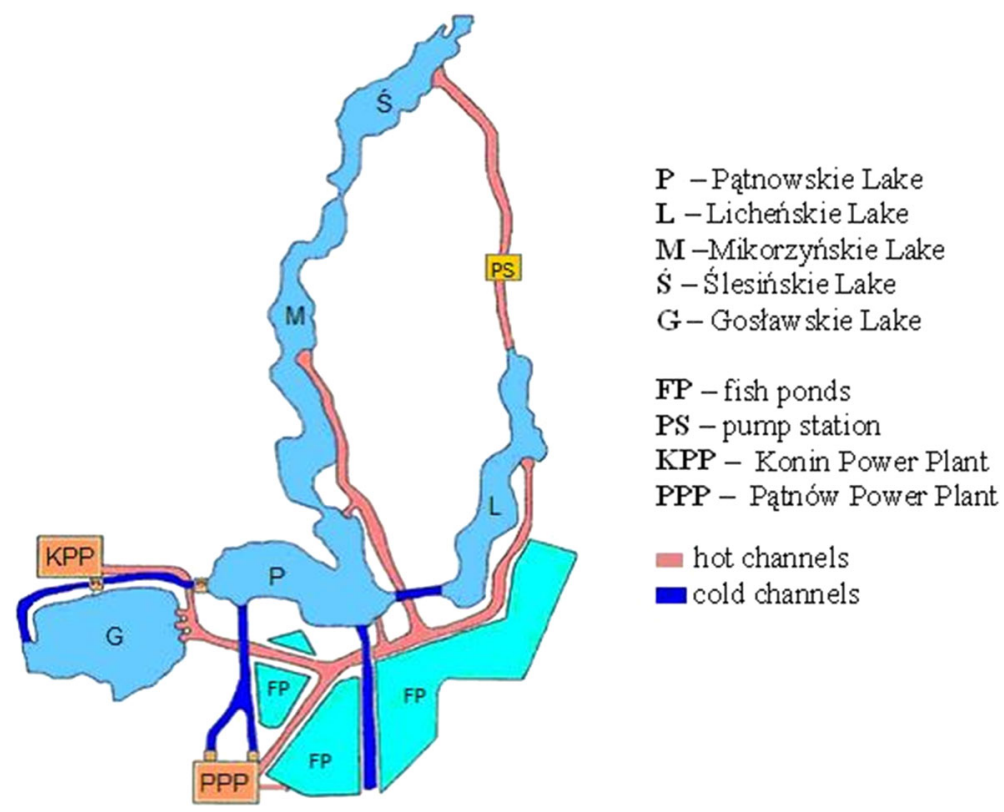


HART498, NAEG1088, and NAE1041. The probes were suspended in the hybridization buffer consisting of formamide (whose concentration depended on the probe sequence [vol/vol]; $\mathrm{NaCl} 0.9 \mathrm{mM}$, sodium dodecyl sulfate $0.01 \%$, Tris/ $\mathrm{HCl}, \mathrm{pH} 7.6,20 \mathrm{mM}$ ). This solution was applied to the surface of the filter with captured cells. For probes LEG705 and LEGPNE1, the formamide concentration was $25 \%$, and for probes NAEG1088 and NAE1041, the formamide concentration was $30 \%$; for probe HART498, the formamide concentration was $40 \%$. The probe concentration in the hybridization buffer was $30 \mathrm{ng}$ of probes for prokaryotic organisms and $150 \mathrm{ng}$ of probes for eukaryotic organisms.

The filters were then placed for $2 \mathrm{~h}$ in a hybridization chamber and in an ultrathermostat at $46^{\circ} \mathrm{C}$. After that, in order to remove the unbound probes, the filters were placed for $15 \mathrm{~min}$ in the washing buffer with a temperature of $48{ }^{\circ} \mathrm{C}$ (the composition of the buffer $-20 \mathrm{mM}$ Tris/HCl, pH 7.6; $0.01 \%$ sodium dodecyl sulfate; $5 \mathrm{mM}$ EDTA; and $160 \mathrm{mM} \mathrm{NaCl}$ for probes LEG705 and LEGPNE1; $5 \mathrm{mM}$ EDTA and $56 \mathrm{mM} \mathrm{NaCl}$ for probe HART498; $5 \mathrm{mM}$ EDTA and $112 \mathrm{mM} \mathrm{NaCl}$ for probes NAEG1088 and NAE1041), rinsed with distilled water, and dried.

Subsequently, the filters were covered with a mixture of immersion oil and Citifluor AF2 (Citifluor Ltd., London, UK). Fluorescence was detected using an Olympus BX50 epifluorescence microscope with a 50-W mercury high-pressure bulb and the appropriate filter set 00 and 10 . The slides with hybridized prokaryotic cells were analyzed at a total of $\times 1,000$ magnification while the slides with eukaryotic cells were analyzed at $\times 100$ and $\times 400$ magnifications. Color micrographs were taken with digital image processing (Olympus XC50) using the software package $\mathrm{Cell}^{\mathrm{B}}$ v. 3.1.. The number of bacteria in the investigated slides was evaluated using the MultiScan Base program.

The sensitivity of the method was controlled with respect to L. pneumophila and eukaryotic cells. To this end, a cell suspension of a known number of cells $\left(10^{3} \mathrm{~cm}^{-3}\right)$ was prepared. Then, $1 \mathrm{ml}$ of the cell suspension was filtered with a membrane filter and the procedure of FISH was performed. After estimation of the number of hybridized cells, the sensitivity of the method was determined.

The tests involved the evaluation of the morphological features of hybridized amoebae with special emphasis on the size and other features typical of the Naegleria and Hartmanella genera. Naegleria spp. are uniform in shape - a cell is $10-15 \mu \mathrm{m}$. The cytoplasm is slightly granular and has a clearly visible bright halo with a dense nucleus. Numerous vacuoles are usually seen in the cytoplasm. Trophozoites move by extending and contracting their rounded pseudopodium (lobopodium), bright on the edges and filled with granular cytoplasm. The posterior end of the cell, a hyaline uroid, has many small pseudopodia.

The trophozoites of Hartmanella reach the size of 25-40 $\mu \mathrm{m}$, have an elongated shape, and produce monopodial lobopodia. The cytoplasm has numerous bright areas, corresponding to vacuolar vesicles. Due to the morphological similarity of pathogenic Naegleria and Hartmanella to non-pathogenic species and due to a slight risk of non-specific binding of the probes to the particles of organic matter after hybridization, the combination of two methods, i.e., molecular (FISH) and morphological, can provide an accurate evaluation of the studied FLA.

The number of amoebae identified by fluorescence in situ hybridization and confirmed in the morphological analysis was recalculated per $1 \mathrm{dm}^{3}$ of the sampled water with the use of the abovementioned formula.

Selecting $N$. fowleri for the research was imposed by their highly pathogenic impact on humans and animals. Selecting Hartmanella was based on the suggestion of Brieland et al. (1997) that the passage of L. pneumophila through Hartmanella seemed to increase the pathogenicity of the bacteria for humans.

Statistical analyses were conducted using program STATISTICA 6.0. Analysis of variance (ANOVA) and correlation were the statistical methods used in calculations. The results were analyzed considering the presence of all investigated phylogenetic bacterial (Legionella sp. and L. pneumophila) and eucaryotic (Naegleria sp., N. fowleri, Hartmanella sp.) groups in relation to the physicochemical parameters of water in the investigated samples of water and the season of the year.

\section{Results}

\subsection{Physicochemical Parameters}

Physicochemical parameters of the collected water are shown in Table 1. During the research period, the average water temperature ranged from $17.66^{\circ} \mathrm{C}$ in October 
Table 1 The physicochemical parameters of the collected water

\begin{tabular}{|c|c|c|c|c|c|c|c|c|c|}
\hline \multirow[t]{2}{*}{ Month } & & \multicolumn{2}{|c|}{ Temperature $\left[{ }^{\circ} \mathrm{C}\right]$} & \multicolumn{2}{|l|}{$\mathrm{pH}$} & \multicolumn{2}{|l|}{$\mathrm{O}_{2}[\%]$} & \multicolumn{2}{|c|}{$\mathrm{O}_{2}[\mathrm{ppm}]$} \\
\hline & & Mean & SD & Mean & $\mathrm{SD}$ & Mean & SD & Mean & $\mathrm{SD}$ \\
\hline \multirow[t]{4}{*}{ Lakes } & May & 20.84 & 3.00 & 8.50 & 0.10 & 167.80 & 61.52 & 14.36 & 6.13 \\
\hline & July & 27.98 & 3.92 & 8.42 & 0.20 & 78.60 & 21.38 & 6.18 & 2.31 \\
\hline & August & 23.08 & 1.96 & 8.40 & 0.12 & 83.20 & 8.83 & 6.94 & 0.80 \\
\hline & October & 17.66 & 1.07 & 7.84 & 0.50 & 96.50 & 31.29 & 8.65 & 3.01 \\
\hline Canals & July & 30.35 & & 8.15 & & 71.00 & & 5.10 & \\
\hline
\end{tabular}

to $27.98{ }^{\circ} \mathrm{C}$ in July. The fluctuations in water temperatures were considered significant $(p<0.01)$. Water in all investigated lakes was alkaline (Table 1). In May, July, and August, slight differences in water $\mathrm{pH}$ were observed. In October, water $\mathrm{pH}$ had the lowest value (7.84). All the investigated lakes and canals had aerobic conditions. The highest oxygen concentration was noted in May while a significantly lower oxygen concentration was noted in July and August. Seasonal fluctuations in water oxygenation were statistically significant $(p<0.05)$ (Table 1).

\subsection{Legionella in the Biofilm and in the Subsurface Water Layer}

Bacteria of the Legionella genus were identified in the collected water samples throughout the entire research period (Fig. 2) The highest numbers of Legionella sp. in the biofilm were noted in May and October, $20.43 \times 10^{3}$ and $13.62 \times 10^{3}$ cells $\mathrm{cm}^{-3}$, respectively. Substantially lower numbers of Legionella sp. were noted in July $\left(4.54 \times 10^{3}\right.$ cells $\left.\mathrm{cm}^{-3}\right)$ and August $(3.02 \times$ $10^{3}$ cells $\mathrm{cm}^{-3}$ ). In the subsurface water layer, the highest number of Legionella sp. was noted in May $\left(4.54 \times 10^{3}\right.$ cells cm $\left.{ }^{-3}\right)$. In July and August, the number decreased by half to further decrease in October when it was $1.51 \times 10^{3}$ cells cm ${ }^{-3}$.

L. pneumophila were identified in the biofilm throughout the entire research period; the highest number was noted in July at $2.27 \times 10^{3}$ cells $\mathrm{cm}^{-3}$. Half of this number was noted in May and October, at $1.51 \times$ $10^{3}$ cells $\mathrm{cm}^{-3}$ (Fig. 3). In the subsurface water layer, L. pneumophila were identified only in July $(1.13 \times$ $10^{3}$ cells $\left.\mathrm{cm}^{-3}\right)$ and August $\left(3.02 \times 10^{3}\right.$ cells cm $\left.{ }^{-3}\right)$. In May, July, and October, L. pneumophila were more abundant in the biofilm. In August, they were more
Fig. 2 The numbers of Legionella sp. and L. pneumophila in lakes serving as a cooling system in a power plant

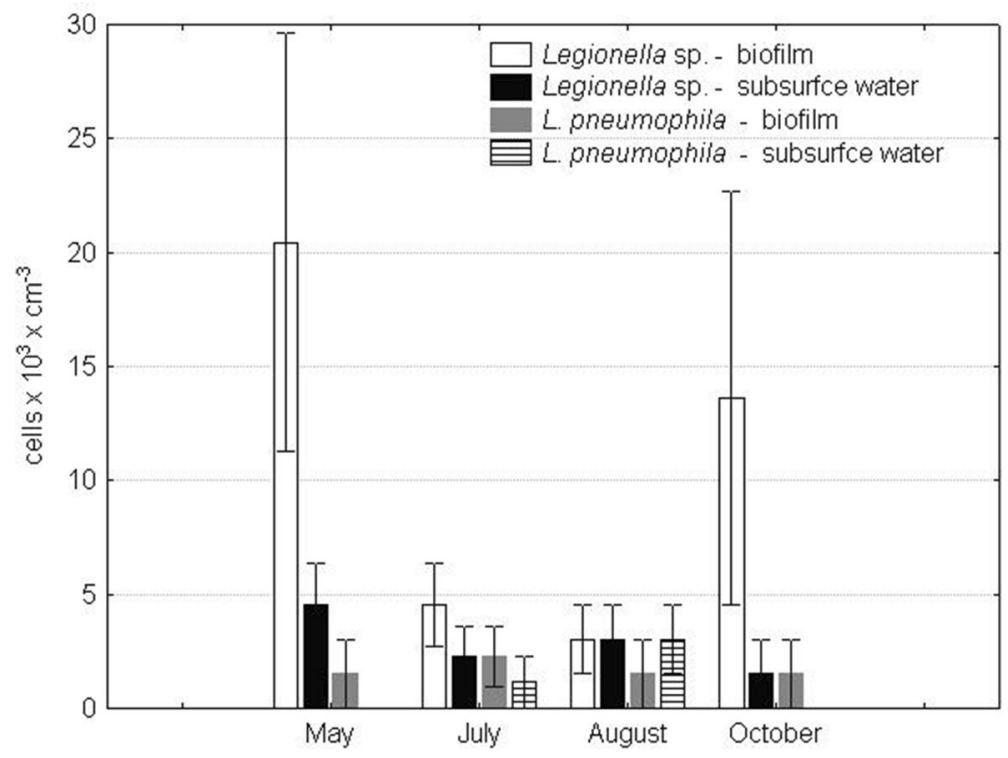




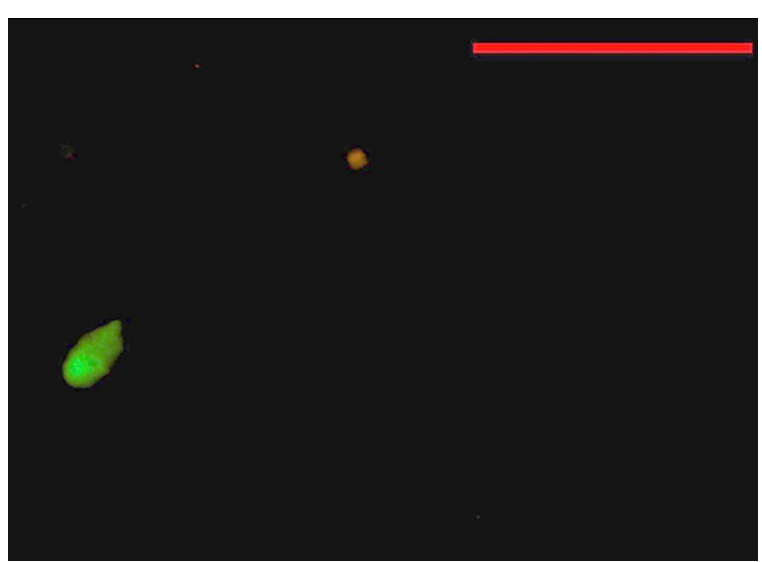

Fig. 3 Positive result of FISH hybridization for Naegleria fowleri; bar $=50 \mathrm{~mm}$

abundant in the subsurface water layer. The number of L. pneumophila in the biofilm was positively correlated with water temperature $(r=0.86)$.

\subsection{FLA in the Biofilm and in the Subsurface Water} Layer

Naegleria sp., N. fowleri, and Hartmanella sp. were identified in the water samples collected from the lakes. Pathogenic N. fowleri (Fig. 3) were identified in the biofilm in summer, at 54 cells $\mathrm{cm}^{-3}$ in July and 57.2 cells $\mathrm{cm}^{-3}$ in August (Table 2). They were also identified in the subsurface water layer in May and August, at 54.4 and 1.6 cells cm$~^{-3}$, respectively.

Amoebae of the Hartmanella genus were more frequently recorded in the biofilm than in the subsurface water layer; in the former, they were identified in May,

Table 2 The numbers of FLA (cells $\mathrm{cm}^{-3}$ ) in lakes serving as a cooling system in a power plant

\begin{tabular}{lllll}
\hline Month & & $\begin{array}{l}\text { Naegleria } \\
\text { sp. }\end{array}$ & $\begin{array}{l}\text { Naegleria } \\
\text { fowleri }\end{array}$ & Hartmanella \\
\hline \multirow{2}{*}{ May } & Biofilm & 0 & 0 & 51.9 \\
& Subsurface water & 52.8 & 54.4 & 53.5 \\
\multirow{4}{*}{ July } & Biofilm & 0 & 53.9 & 55.1 \\
& Subsurface water & 0 & 0 & 0 \\
\multirow{4}{*}{ October } & Biofilm & 0 & 57.2 & 0 \\
& Subsurface water & 0 & 1.6 & 0 \\
& Biofilm & 0 & 0 & 54.7 \\
& Subsurface water & 0 & 0 & 0 \\
\hline
\end{tabular}

July, and October and the recorded number was always 54.4 cells $\mathrm{cm}^{-3}$ (Table 2). In the latter, they were identified only in May $\left(54.4\right.$ cells $\left.\mathrm{cm}^{-3}\right)$. Hartmanella (Fig. 4) were not identified in any of the samples collected from the discharge canals.

Naegleria spp. were not identified in the biofilm throughout the entire research period. In the subsurface water layer, they were identified only in May $\left(54.4\right.$ cells $\left.\mathrm{cm}^{-3}\right)$. In the subsurface water layer, the number of all investigated FLA was positively correlated with water oxygenation $(r=0.96)$ and with the number of Legionella ( $r$ ranging from 0.88 to 0.90$)$.

\section{Discussion}

Common in aquatic environments, bacteria belonging to the Legionella genus have been identified in natural and man-made (anthropogenic) water bodies (Diederen 2008), in the biofilm and in the subsurface water layer. Their growth rate depends on several chemical and physical factors including temperature, water $\mathrm{pH}$, and the concentration of compounds dissolved or suspended in water, as well as on biological factors including the presence of several groups of Eubacteria, Cyanophyta, and Protista.

Known to play a fundamental role in the growth of L. pneumophila, water temperature and oxygenation were subject to the most considerable seasonal

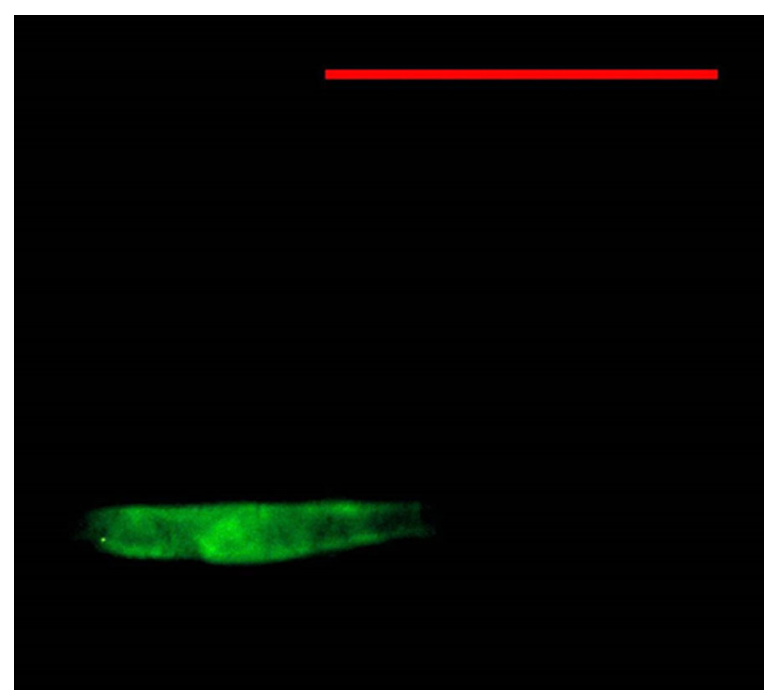

Fig. 4 Positive result of FISH hybridization for Hartmanella; bar $=50 \mathrm{~mm}$ 
fluctuations in the investigated lakes (the cooling system of a power plant). In addition, previous studies indicate that a higher temperature intensifies the mineralization of organic matter and increases the growth rate of bacteria (Zdanowski 1998), including L. pneumophila (Devos et al. 2005; Declerck 2010).

The results of the microbiological tests indicate that bacteria belonging to the Legionella genus were common in the investigated lakes and canals, with their highest number recorded in May. According to Świątecki and Zdanowski (2007), in May, massive algal and cyanobacterial blooms can be expected. What is more, the results of Declerck's research (Declerck 2010) suggest that photosynthetic cyanobacteria are able to promote the growth of Legionella. However, despite the high number of Legionella, in spring, the number of $L$. pneumophila was rather low and they were identified only in the biofilm. This may be related to the low water temperature (in May, $21{ }^{\circ} \mathrm{C}$ on average); although the temperature range for the growth of L. pneumophila falls between 20 and $40{ }^{\circ} \mathrm{C}$ (Grabińska-Loniewska 2010; Diederen, 2008), the temperature ensuring their optimal growth rate ranges from 32 to $35^{\circ} \mathrm{C}$.

In July, despite the significantly lower number of Legionella sp., the number of L. pneumophila increased, which may be attributed to the considerable rise in water temperature $\left(29^{\circ} \mathrm{C}\right.$ on average). Owing to favorable conditions, water in the discharge canals also contained high numbers of $L$. pneumophila. High water temperature (above $28^{\circ} \mathrm{C}$ ), good aerobic conditions, and high number of Eubacteria contributed tremendously to the growth of these bacteria.

In August, the populations of Legionella sp. and L. pneumophila in the biofilm decreased slightly as a result of deficiency or exhaustion of easily digestible organic matter (Zdanowski 1998). However, Devos et al. (2005) suggest that the decrease may be related to the emergence of bacteria that inhibit the growth of Legionella. According to Toze et al. (1990), $32 \%$ of heterotrophic bacteria including Pseudomonas sp. and Aeromonas sp. can inhibit the growth of Legionella sp. Similar results documenting the decrease in the number of Legionella sp. and L. pneumophila in late summer were obtained by Declerck et al. (2007a).

During autumn, in the biofilm, the number of Legionella sp. and L. pneumophila increased in the fall despite the temperature drop $\left(13.62 \times 10^{3}\right.$ and $1.51 \times$ $10^{3}$ cells $\mathrm{cm}^{-3}$, respectively). In view of the fact that, according to Devos et al. (2005), Legionella can obtain essential nutrients from decaying organic matter, the observed accumulation of particulate organic matter in the biofilm may have increased the number of these bacteria. In addition, as has been reported in numerous studies, the accumulation of organic matter and the subsequent rapid growth of bacteria can be observed in the biofilm (Walczak and Swiontek-Brzezinska 2010; Burkowska et al. 2010). By contrast, the number of L. pneumophila in the subsurface water layer was very low. This fact can be attributed to different conditions in this microenvironment (no biofilm formation).

L. pneumophila were identified in the biofilm throughout the entire research period. Their presence in natural water bodies is correlated with the presence of other microorganisms, a valuable source of exogenous amino acids.

Numerous studies indicate that the growth of L. pneumophila in aquatic environments (along with biofilm) is promoted by three microbial groups, i.e., amoebae, cyanobacteria, and some heterotrophic bacteria (Devos et al. 2005; Declerck 2010) including Flavobacterium sp., Alcaligenes sp., and Acinetobacter sp. All the heterotrophic bacteria species were previously identified in the biofilm by Donderski et al. (1999) and Kalwasińska and Donderski (2005). Moreover, the survival rate of L. pneumophila in biofilm may be enhanced by the algae Scenedesmus spp., Chlorella spp., and Gleocystis spp. as well as by free-living amoebae, which, according to Loret and Greub (2010), are commonly found at the edges of biofilms, where they can feed on ample amounts of algae, fungi, and bacteria.

In the investigated lakes, Hartmanella sp. and $N$. fowleri were identified in the biofilm throughout the entire research period (Table 2). In the symbiotic relationship between pathogenic strains of Legionella and FLA described by Greub and Raoult (2003), Declerck et al. (2007b), Hsu et al. (2009), Buse and Ashbolt (2011), and others, FLA protect the bacteria from unfavorable environmental conditions (Borella et al. 2005; Marciano-Cabral et al. 2010) while rapidly multiplying bacteria provide FLA with nutrients (Greub and Raoult 2004).

In the anthropogenically altered environments, the symbiotic relationship between pathogenic amoebae (particularly N. fowleri) and pathogenic bacteria poses a serious health risk for humans. The investigated lakes serving as a cooling system of a power plant are also a recreational area. The solid (floating) and dispersed 
(aerosol) biofilms containing pathogens pose a serious risk for swimmers and amateurs of water sports (Goutziana et al. 2008). The risk is increased by the fact that the growth of $N$. fowleri in thermally polluted aquatic environments in colder regions of the world is not naturally regulated by other thermophilic microorganisms competing with pathogenic FLA (Marciano-Cabral 1988).

The number of pathogenic amoebae in the collected water samples ranged from 0.0 to 57.2 cells $\mathrm{cm}^{-3}$, the values which can be perceived as a real threat to human health. Although a dangerous level of $N$. fowleri was not determined for the freshwater bodies, Cabanes et al. (2001) using mouse models for experimental inoculation assessed that the probability of infection in swimmers is $8.5 \times 10^{-8}$ with an amoebae concentration of 100 cells $\mathrm{dm}^{-3}$. However, even a lower concentration of amoebae $\left(25\right.$ cells $\left.\mathrm{dm}^{-3}\right)$ was responsible for seven cases of infection in humans in Florida, USA (Wellings et al. 1977). A dangerous infective level of L. pneumophila is considered to be $1 \times 10^{3}$ cells $\mathrm{cm}^{-3}$, which is capable of growing on culture media. The results of the present research indicate a higher level of these bacteria in the investigated lakes. However, the research was based on the molecular FISH method, used for detection of both culturable and non-culturable cells. The prior validation of the method indicates that its sensitivity in this case is about 100 to 1,000 times higher than the sensitivity of the culture method, which therefore implies that the concentration of L. pneumophila did not exceed the invasive level.

\section{Conclusions}

In temperate climates, natural but thermally altered aquatic environments provide perfect conditions for the growth of L. pneumophila and potentially pathogenic amoebae. The fact that the concentration of both L. pneumophila and FLA was higher in the biofilm than in the subsurface water layer indicates an increased risk of the invasion of pathogenic microorganisms in amateurs of water sports. Since seasonal fluctuations in the number of these organisms in the biofilm are directly connected with a temperature rise (the highest temperatures recorded in the peak of the summer season), monitoring freshwater bodies for the presence of these pathogens seems of the utmost importance.
Acknowledgments This research has been carried out with thanks to the State Committee for Scientific Research, grant no. 3878/B/P01/2010/38.

Open Access This article is distributed under the terms of the Creative Commons Attribution License which permits any use, distribution, and reproduction in any medium, provided the original author(s) and the source are credited.

\section{References}

Borella, P., Guerrieri, E., Marchesi, I., Bondi, M., \& Messi, P. (2005). Water ecology of Legionella and protozoan: environmental and public health perspectives. Biotechnology Annual Review, 11, 355-80.

Brieland, J. K., Fantone, J. C., Remick, D. G., LeGendre, M., McClain, M., \& Engleberg, N. C. (1997). The role of Legionella pneumophila-infected Hartmanella vermiformisas an infectious particle in a murine model of Legionnaires' disease. Infection and Immunity, 65, 53305333.

Brown, T. J., Cursons, R. T., Keys, E. A., Marks, M., \& Miles, M. (1983). The occurrence and distribution of pathogenic freeliving amoebae in thermal areas of the north island of New Zealand. New Zealand Journal of Marine \& Freshwater Research, 17, 59-69.

Burkowska, A., Walczak, M., \& Donderski, W. (2010). The impact of UV radiation on metabolism of neustonic and planktonic bacteria in eutrophic lake. Polish Journal of Ecology, 58, 211-219.

Buse, H. Y., \& Ashbolt, N. J. (2011). Differential growth of Legionella pneumophila strains within a range of amoebae at various temperatures associated with in-premise plumbing. Letters in Applied Microbiology, 53, 217-24.

Cabanes, P. A., Wallet, F., Prinquez, E., \& Pernin, P. (2001). Assessing the risk of primary amoebic meningoencephalitis from swimming in the presence of environmental Naegleria fowleri. Applied and Environmental Microbiology, 67, 29272931.

Červa, L., \& Novák, K. (1968). Ameobic meningoencephalitis: sixteen fatalities. Science, 160, 92.

Craun, G. F., Calderon, R. L., \& Craun, M. F. (2005). Outbreaks associated with recreational water in the United States. International Journal of Environmental Health Research, 15, 243-262.

De Napoli, T. S., Rutman, J. Y., Robinson, J. R., \& Rhodes, M. M. (1996). Primary amoebic meningoencephalitis after swimming in the Rio Grande. Texas Medicine, 92, 59-63.

Declerck, P. (2010). Biofilms: the environmental playground of Legionella pneumophila. Environmental Microbiology, 12, 557-566.

Declerck, P., Behets, J., van Hoef, V., \& Ollevier, F. (2007a). Replication of Legionella pneumophila in floating biofilms. Current Microbiology, 55, 435-440.

Declerck, P., Behets, J., van Hoef, V., \& Ollevier, F. (2007b). Detection of Legionella spp. and some of their amoeba hosts in floating biofilms from anthropogenic and natural aquatic environments. Water Research, 41, 3159-3167. 
Dendana, F., Sellami, H., Jarraya, F., Sellami, A., Makni, F., Cheikhrouhou, F., Hachicha, J., \& Ayadi, A. (2008). Freeliving amoebae (FLA): detection, morphological and molecular identification of Acanthamoeba genus in the hydraulic system of an haemodialysis unit in Tunisia. Parasite, 15, 137-42.

Devos, L., Boon, N., \& Verstraete, W. (2005). Legionella pneumophila in the environment: the occurrence of a fastidious bacterium in oligotrophic conditions. Reviews in Environmental Science and Biotechnology, 4, 61-74.

Diederen, B. M. (2008). Legionella spp. and Legionnaires' disease. Journal of Infection, 56, 1-12.

Donderski, W., Walczak, M., Mudry, Z., \& Kobyliński, M. (1999). Neustonic bacteria number, biomass and taxonomy. Polish Journal of Environmental Studies, 8, 137-141.

Fields, B. S. (1996). The molecular ecology of Legionellae. Trends in Microbiology, 4, 86-90.

Fields, B. S., Benson, R. F., \& Besser, R. E. (2002). Legionella and Legionnaires' disease: 25 years of investigation. Clinical Microbiology Reviews, 15, 506-526.

Fiordalisi, I., Christie, J., \& Moffitt, C. (1992). Amebic meningoencephalitis - north Carolina 1991. Morbid-Mortal Weekly Report, 41, 437-439.

Flemming, H. C., Wingeneder, J., Mayer, C., Körstgens, V., \& Borchard, W. (2000). Cohesiveness in biofilm matrix polymers. In D. G. Allison, H. M. Lapin-Scott, \& M. Wilson (Eds.), Society for General Microbiology Symposium: community structure and co-operation in biofilms (pp. 88-106). Cambridge: University Press.

Gomez-Valero, L., Rusniok, C., \& Buchrieser, C. (2009). Legionella pneumophila: population genetics, phylogeny and genomics. Infection, Genetics and Evolution, 9, 727-739.

Goutziana, G., Mouchtouri, V. A., Karanika, M., Kavagias, A., Stathakis, N. E., Gourgoulianis, K., Kremastinou, J., \& Hadjichristodoulou, C. (2008). Legionella species colonization of water distribution systems, pools and air conditioning systems in cruise ships and ferries. BioMed Central Public Health. doi:10.1186/1471-2458-8-390.

Grabińska-Łoniewska, A. (2010). Mikroorganizmy chorobotwórcze $i$ potencjalnie chorobotwórcze $w$ ekosystemach wodnych $i$ sieciach wodociagowych, Wydawnictwo: Seidel-Przywecki

Greub, G., \& Raoult, D. (2003). Morphology of Legionella pneumophila according to their location within Hartmanella vermiformis. Research in Microbiology, 154, 619-21.

Greub, G., \& Raoult, D. (2004). Microorganisms resistant to freeliving amoebae. Clinical Microbiology Reviews, 17, 413433.

Grimm, D., Ludwig, W., Brandt, B. C., Michel, R., Schleifer, K. H., Hacker, J., \& Steinert, M. (2001). Development of $18 \mathrm{~S}$ rRNA-targeted oligonucleotide probes for specific detection of Hartmanella and Naegleria in Legionella-positive environmental samples. Systematic and Applied Microbiology, 24, 76-82.

Guyard, C., \& Low, D. (2011). Legionella infections and travel associated legionellosis. Travel Medicine and Infectious Disease, 9, 176-186.

Gyori, E. (2003). December 2002: 19-year old male with febrile illness after jet ski accident. Brain Pathology, 13, 237-239.

Henke, M., \& Seidel, K. M. (1986). Association between Legionella pneumophila and amoebae in water. Israel Journal of Medical Sciences, 22, 690-695.
Hsu, B. M., Lin, C. L., \& Shih, F. C. (2009). Survey of pathogenic free-living amoebae and Legionella spp. in mud spring recreation area. Water Research, 43, 2817-2828.

Huang, S. W., \& Hsu, B. M. (2010). Survey of Naegleria and its resisting bacteria-Legionella in hot spring water of Taiwan using molecular method. Parasitology Research, 106, 3951402.

John, D. T., \& Howard, M. J. (1995). Seasonal distribution of pathogenic free-living amebae in Oklahoma waters. Parasitology Research, 81, 193-201.

Kalwasińska, A., \& Donderski, W. (2005). Neustonic versus planktonic bacteria in eutrophic lake. Polish Journal of Ecology, 53, 571-577.

Kramer, M. H., \& Ford, T. E. (1994). Legionellosis: ecological factors of an environmentally 'new' disease. Zentralblatt für Hygiene und Umweltmedizin, 195, 470-482.

Kyle, D. E., \& Noblet, G. P. (1985). Vertical distribution of potentially pathogenic amoeba in freshwater lakes. Journal of Protozoology, 32, 99-105.

Lee, J. V., \& West, A. A. (1991). Survival and growth of Legionella species in the environment. Society of Applied Bacteriology Symposium Series, 20, 121S-129S.

Loret, J. F., \& Greub, G. (2010). Free-living amoebae: biological by-passes in water treatment. International Journal of Hygiene and Environmental Health, 213, 167-175.

Mackowiak, P. A., Norton, R., Harris, P., Ryan, P., \& Simpson, S. (2010). Another killer of the Australian bush: a rapidly fatal meningoencephalitis in a child. Clinical Infectious Diseases, 50(10), 1422-1424.

Marciano-Cabral, F. (1988). Biology of Naegleria spp. Microbiology and Molecular Biology Reviews, 52, 114-133.

Marciano-Cabral, F., MacLean, R., Mensah, A., \& LaPat-Polasko, L. (2003). Identification of Naegleria fowleri in domestic water sources by nested PCR. Applied and Environmental Microbiology, 69, 5864-5869.

Marciano-Cabral, F., Jamerson, M., \& Kaneshiro, E. S. (2010). Free-living amoebae, Legionella and Mycobacterium in tap water supplied by a municipal drinking water utility in the USA. Journal of Water and Health, 8, 71-82.

Martinez, A. J. (1985). Free-living amoebas: natural history, prevention, diagnosis, pathology, and treatment of disease. Florida: CRC Press Boca Raton.

Okuda, D. T., Hanna, H. J., Coons, S. W., \& Bodensteiner, J. B. (2004). Naegleria fowleri hemorrhagic meningoencephalitis: report of two fatalities in children. Journal of Child Neurology, 19, 231-233.

Pancer, K., Rabczenko, D., Krogulska, B., Matuszewska, R., Ozygała, J., Stanisławska, A., Trzcińska, A., \& Stypułkowska-Misiurewicz, H. (2008). Mikrobiologiczna ocena zagrożenia legionelozą oraz zastosowanie metody eliminacji Legionella pneumophila z sieci wodociagowych budynków szpitalnych. Przegla d Epidemiologiczny, 62, 439-446.

Paszko-Kolva, C., Shahamat, M., \& Colwell, R. R. (1993). Effect of temperature on survival of Legionella pneumophila in the aquatic environment. Microbial Releases, 2, 73-79.

Pélandakis, M., \& Pernin, P. (2002). Use of multiplex PCR and PCR restriction enzyme analysis for detection and exploration of the variability in the free-living amoeba Naegleria in 
the environment. Applied and Environmental Microbiology, 68, 2061-2065.

Reveiller, F. L., Cabanes, P. A., \& Marciano-Cabral, F. (2002). Development of a nested PCR assay to detect the pathogenic free-living amoeba Naegleria fowleri. Parasitology Research, 88, 443-450.

Saint, C. P., \& Ho, L. (1999). A PCR test for identification and discrimination of Legionella longbeachae serogroups 1 and 2. Journal of Microbiological Methods, 37, 245-3.

Schuster, F. L., \& Visvesvara, G. S. (2004). Amebae and ciliated protozoa as causal agents of waterborne zoonotic disease. Veterinary Parasitology, 126, 91-120.

Shin, H.-J., \& Im, K. (2004). Pathogenic free-living amoebae in Korea. Korean Journal of Parasitology, 42, 93-119.

Singh, B. N., \& Dutta, G. D. P. (1984). Small free-living aerobic amoebae: soil as a suitable habitat, isolation, culture, classification, pathogenicity, and epidemiology. International Journal for Parasitology, 8, 1-23.

States, S. J., Conley, L. F., Knezevich, C. R., Keleti, G., Sykora, J. L., Wadowsky, R. M., Yee, R.B. (1989). Free-living amoebae in public water supplies: implications for Legionella, Giardia, and Cryptosporidia. In Proceedings Water Quality Technology Conference Advances in Water Analysis and Treatment (pp. 109-125). St. Louis, Missouri

Steinert, M., Hentschel, U., \& Hacker, J. (2002). Legionella pneumophila: an aquatic micro goes astray. Federation of European Microbiological Societies Microbiology Reviews, 26, 149-162.

Stevens, A. R., Tyndall, R. L., Coutant, C. C., \& Willaert, E. (1977). Isolation of the etiological agent of primary amoebic meningoencephalitis from artificially heated waters. Applied and Environmental Microbiology, 34, 701-705.

Świątecki, A., \& Zdanowski, B. (2007). The seasonal dynamics of organic matter remineralization by bacterial consortia in the heated Konin lakes. Archives of Polish Fisheries, 15, 309320.

Sykora, J. L., Keleti, G., \& Martinez, A. J. (1983). Occurrence and pathogenicity of Naegleria fowleri in artificially heated waters. Applied and Environmental Microbiology, 45(3), 974 979.

Taylor, J. P., Hendricks, K. A., \& Dingley, D. D. (1996). Amoebic meningoencephalitis. Infections in Medicine, 13, 1021-1024.
Toze, S., Sly, L. I., Macrae, I. C., \& Fuerst, J. A. (1990). Inhibition of growth of Legionella species by heterotrophic plate-count bacteria isolated from chlorinated drinking water. Current Microbiology, 21, 139-143.

Tyndall, R. L., Ironside, K. S., Metler, P. L., Tan, E. L., Hazen, T. C., \& Fliermans, C. B. (1989). Effect of thermal additions on the density and distribution of thermophilic amoebae and pathogenic Naegleria fowleri in a newly created cooling lake. Applied and Environmental Microbiology, 55, 722-732.

Vandenesch, F., Surgot, M., Bornstein, N., Paucod, J. C., Marmet, D., Isoard, P., \& Fleurette, J. (1990). Relationship between free amoeba and Legionella: studies in vitro and in vivo. Zentralblatt fur Bakteriologie, 272, 265-275.

Visvesvara, G. S., Moura, H., \& Schuster, F. L. (2007). Pathogenic and opportunistic free-living amoebae: Acanthamoeba spp., Balamuthia mandrillaris, Naegleria fowleri, and Sappinia diploidea. Federation of European Microbiological Societies Immunology and Medical Microbiology, 50, 1-26. doi:10.1111/j.1574-695X.2007.00232.x.

Walczak, M., \& Swiontek-Brzezinska, M. (2010). Phylogenetic diversity and abundance of bacteria from surface and subsurface water in eutrophic lake. Polish Journal of Ecology, 58, 177-186.

Walczak, M., Krawiec, A., \& Lalke-Porczyk, E. (2013). Legionella pneumophila bacteria in thermal saline bath. Annals of Agricultural and Environmental Medicine, 20, 697-700.

Wellings, F. M., Amuso, P. T., Chang, S. L., \& Lewis, A. L. (1977). Isolation and identification of pathogenic Naegleria from Florida lakes. Applied and Environmental Microbiology, 34, 661-667.

Whiley, H., \& Bentham, R. (2011). Legionella longbeachae and legionellosis. Emerging Infectious. Diseases, 17, 579-583.

Żbikowska, E., Walczak, M., \& Krawiec, A. (2013). Distribution of Legionella pneumophila bacteria and Naegleria and Hartmanella amoebae in thermal saline baths used in balneotherapy. Parasitology Research, 112, 77-83.

Zdanowski, B. (1998). Jeziora konińskie - 40 lat badań. Stan aktualny oraz wnioski dla ochrony. In WIOŚ (Ed.), Biblioteka Monitoringu Środowiska (pp. 45-51). Konin, Poland. 